\title{
Webliography of STI indicator databases and related publications
}

\author{
Anup Kumar Das, ${ }^{1}$ Parveen Arora ${ }^{2}$ and Sujit Bhattacharyaa ${ }^{3, *}$ \\ ${ }^{1}$ Centre for Studies in Science Policy, Jawaharlal Nehru University, New Delhi, India \\ ${ }^{2}$ NSTMIS Division, Department of Science and Technology, New Delhi, India \\ ${ }^{3}$ CSIR-National Institute of Science, Technology and Development Studies, New Delhi, India
}

\begin{abstract}
The Science, Technology and Innovation (STI) indicators have become essential tools for assessing knowledge capacity in a country or a region and as evidence for setting policy actions. Indicator development has become possible primarily because of two parallel efforts: collection and compilation of global, regional and national statistics on various dimensions of STI, and development of manuals/guidelines for their proper collection. These statistics and indicators are mostly available in the form of print or online publications as well as in the form of online databases or as sub datasets of online data portals. An indicative list of global, regional and national databases and publications is given in this webliography for engaging readers with STI indicators and related tools. Some of the key manuals/guidelines are also highlighted.
\end{abstract}

\section{DEFINING STI INDICATORS}

Science, Technology and Innovation Indicators or STI indicators usually refer to a range of parameters in determining the innovative potentials of industries, availability of $R \& D$ infrastructure, availability of $R \& D$ funding, availability of funding for successful commercialization of innovative solutions, and availability of qualified R\&D manpower. STI indicators also indicate a country's readiness in taking part in the knowledge economy and building knowledge societies. OECD member countries are already engaged in building knowledge societies with significant investment in their respective knowledge economy. Other emerging economies are also following these advanced countries in achieving higher score in STI indicators. STI indicators are also interlinked with a country's

*Corresponding author.

Sujit Bhattacharya

CSIR-National Institute of Science, Technology and Development Studies,

New Delhi, India

E-mail: sujit_academic@yahoo.com

DOI: 10.5530/jscires.2012.1.14 socio-economic indicators, such as ranking in Human Development Index, World Development Indicators, and World Trade Indicators. Project on the History \& Sociology of STI Statistics of Canada' is one of the most influential works that provides a detailed perspective of indicator development. Interested readers are referred to the various reports available online (outcome of this project) for an informed understanding of the development of STI indicators.

\section{GLOBAL DATABASES}

(I) S\&T Data Centre of UNESCO, Institute for Statistics (www.uis.unesco.org/ScienceTechnology/)

UNESCO Institute for Statistics (UIS) produces global S\&T statistics, called A Global Perspective on Science and Technology, covering more than 200 countries and territories through its biennial research and experimental development survey. UIS collaborates with intergovernmental statistical organizations such as Eurostat, OECD, RICYT and also individual national S\&T collection agencies for collecting S\&T data from member countries of United Nations. The data provides a global perspective that is relevant to policymakers on the state of science and research infrastructure.

UIS Data Centre is an open data platform and provides direct access to S\&T data tables of any country or region. UIS S\&T statistics is also available at UNDATA (http:// data.un.org/explorer.aspx) portal, an open data initiative of the United Nations (UNDATA also provides access to global indicators related to energy, environment, telecommunications, agriculture, bealth, trade and all other major areas).

Statistics generated by UNESCO is liberally used by other international agencies, national bodies, etc. in developing their S\&T database and indicators, and developing new guidelines (for example by OECD, RICYT, etc). UNESCO also brings out publications that provide 
assessment of global S\&T. UNESCO Science Report is one of its key publications in this domain. It was launched in 1993 under the name of World Science Report. Since then, five reports have provided periodic review of the state of science around the world - emerging trends in scientific research and higher education, by country or by region. The five reports (1993, 1996, 1998, 2005 and 2010) are available from (http://www.unesco.org/new/ en/natural-sciences/science-technology/prospectivestudies/unesco-science-report/).

The UIS is involved in creating statistics that shows the state of innovation activity in different countries. The ultimate goal of the UIS is to create an international database of innovation statistics for countries at all stages of development. The first step entails the construction of an inventory of innovation surveys that have been carried out in developing countries. In addition, they have also developed a pilot data collection that was scheduled to be conducted in 2011. The plan is to launch a global data collection in 2013, which will be conducted on a biennial basis. To this end, the UIS is working close with a group of experts while strengthening relations with regional and international organizations.

(II) OECD Science, Technology and R\&D Statistics (http://www.oecd.org/sti/)

Organization for Economic Cooperation and Development (OECD) produces OECD Science, Technology and R\&D Statistics, which is an online interactive subscriptionbased platform. OECD Science, Technology and R\&D Statistics is a package that includes two databases titled Basic Science and Technology Statistics and Main Science and Technology Indicators.

- Basic Science and Technology Statistics includes resources devoted to research and development (R\&D) and indicators of the results of science and technology (S\&T) activities, such as patents and technology balance of payments. This database also provides statistical data tables on government researchers, gross domestic expenditure on R\&D (GERD), and women researchers.

- Main Science and Technology Indicators (ISSN: 1011-792X (print); (www.oecd.org/sti/msti) is a statistical periodical published twice yearly, covering most frequently used indicators on the scientific and technological performance of the OECD member countries, such as resources devoted to $\mathrm{R} \& \mathrm{D}$, measures of output and the impact on S\&T activities (patents, technology balance of payments, trade in high-technology industries).
In addition to above-mentioned two databases, online OECD Science, Technology and R\&D Statistics platform includes two spin-off products, namely,

- OECD Science, Technology and Industry Scoreboard 2011 (biennial statistical publication), and

- OECD Science, Technology and Industry Outlook 2010 (biennial statistical publication).

OECD Science, Technology and R\&D Statistics also provides access to two related databases in the package, namely, OECD Patent Statistics, and OECD Telecommunications and Internet Statistics.

The coverage of OECD databases is mainly OECD member countries and few non-member economies (Argentina, China, India, Israel, Romania, Russian Federation, Singapore, Slovenia, South Africa, and Chinese Taipei). Some regular OECD publications also include statistics of other emerging economies. OECD also provides open access to basic statistical tables and ready references to $\mathrm{S} \& \mathrm{~T}$ indicators and R\&D statistics through its 'OECD. Stat Extracts' (http://stats.oecd.org/Index.aspx) online portal.

\section{(III) Agricultural Science and Technology} Indicators (ASTI) (www.asti.cgiar.org)

The CGIAR Consortium (Consortium of International Agricultural Research Centers), in collaboration with International Food Policy Research Institute (IFPRI), produces the Agricultural Science and Technology Indicators (ASTI), an open data portal for agricultural S\&T indicators and statistics. ASTI aims to provide "internationally comparable data on agricultural R\&D investments and capacity for developing countries". ASTI provides access to quantitative and qualitative data on investment, capacity, and institutional trends in agricultural $R \& D$ in low and middle-income countries. ASTI produces interactive map and data charts on the given indicators, such as total agricultural R\&D spending, agricultural research staff, agricultural research funding sources, agricultural research focus, socio-economic indicators, and socio-economic ratios (e.g. public agricultural research staff per million population, public agricultural R\&D spending per capita, etc.).

ASTI collects data through structured survey forms in collaboration with its various regional and national partners. Based on its quantitative and qualitative data, ASTI produces analytical reports and country reports for global, regional and national agricultural policymaking. Some of its influential publications are: 
- Beintema, Nienke and Stads, Gert-Jan (2011). African Agricultural R\&D in the New Millennium: Progress for Some, Challenges for Many. Rome: Agricultural Science and Technology Indicators.

- Stads, Gert-Jan and Beintema Nienke (2009). Public Agricultural Research in Latin America and the Caribbean: Investment and Capacity Trends. Rome: Agricultural Science and Technology Indicators.

- Beintema, Nienke M. and Stads, Gert-Jan (2008). Diversity in Agricultural Research Resources in the Asia-Pacific Region. Bangkok: Asia-Pacific Association of Agricultural Research Institutions (APAARI).

\section{REGIONAL DATABASES}

\section{[A] Science, Technology and Innovation Indicators in Europe}

\section{(I) Eurostat (bttp://epp.eurostat.ec.europa.eu/)}

European Commission's Eurostat produces annual pocketbook publication titled 'Science, Technology and Innovation in Europe' draws a comprehensive picture of the science, technology and innovation activities in the European Union as carried out by its people, enterprises and governments. It provides statistical information on evolution and composition of science and technology in Europe and its position with regard to its partners. Its print edition in 2012 comprises of seven chapters, namely: Government budget appropriations or outlays on R\&D (GBAORD); $\mathrm{R} \& \mathrm{D}$ expenditure; $\mathrm{R} \& \mathrm{D}$ personnel; Human resources in S\&T; Innovation; Patents; and High-technology.

Eurostat also provides open access to statistical database and main tables of the Science, Technology and Innovation in Europe through its online portal (http://epp. eurostat.ec.europa.eu/). Its 2012 edition as well as its earlier editions is freely downloaded from Eurostat website. The influential reports on STI emerging from Eurostat are:

- Eurostat (2012). Science, Technology and Innovation in Europe: 2012 Edition. Luxembourg: Publications Office of the European Union. ISBN: 978-92-7921874-3. URL: (http://epp.eurostat.ec.europa.eu/ cache/ITY_OFFPUB/KS-GN-12-001/EN/KSGN-12-001-EN.PDF).

- European Communities (2003). Third European Report on Science \& Technology Indicators 2003: Towards a Knowledgebased Economy. Luxembourg: Office for Official Publications of the European Communities. ISBN 92-894-1795-1 URL: (ftp://ftp.cordis.europa.eu/pub/ indicators/docs/3rd_report.pdf).

\section{(II) ERAWATCH (bttp://erawatch.jrc.ec.europa.eu/)}

Erawatch is an open data portal that provides information on European, national and regional research systems, STI indicators, policies, and programmes in the EU and beyond. It contributes as an inventory and observatory in realisation of the European Research Area (ERA). It supports evidence based policy making in Europe. Erawatch currently covers 61 countries: the 27 member states of the European Union, 13 countries associated with the European community's Research Framework Programme and 21 developing countries. Erawatch information is collected and presented by Erawatch network of national experts. It also provides access to INNO-Policy TrendChart. The INNO-Policy TrendChart tracks developments in innovation policy measures throughout Europe and other associated countries. The innovation policy measures for each individual country are also accessible via the country pages, which provide a single gateway for all information held by the INNO-Policy TrendChart about individual countries. A country profile usually includes an overview, national research policy, regional research policies, policy mix, governance structures, research funders, research performers, national policy and European research area, internationalisation of S\&T cooperation and key research indicators.

Erawatch also provides an Interactive Statistical Tool, based on the Regional key figures database of Eurostat. This tool allows comparison of specific indicators within time, space and those sectors where data are available. Erawatch and INNO-Policy TrendChart jointly constitute the European Inventory of Research and Innovation Policy Measures. Pro-Inno Europe (http://www.proinno-europe. $\mathrm{eu} /$ ) is the related initiative of EU's Directorate General Enterprise and Industry which aims to become the focal point for innovation policy analysis and policy cooperation in Europe.

[B] Science, Technology and Innovation Indicators in Latin America

\section{The Ibero-American and Inter-American Network on Science and Technology Indicators (RICYT) (bttp://www.ricyt.org)}

The RICYT is an inter-American regional network covering countries from Latin America and North America. RICYT maintains a database for STI indicators for the region through its portal. RICYT indicators include: context indicators (covering socio-economic), input indicators (covering financial resources and human resources), 
higher education graduates, patents indicators, and bibliometric indicators. This section is called 'comparatives' to compare between countries and years. A downloadable data table is generated when click on a particular indicator, while online accessing the database.

RICYT maintains a separate database Politicas CTI (www. politicascti.net) for providing open access to instruments and policies in STI in Latin America and the Caribbean. Based on its quantitative and qualitative data, RICYT produces analytical reports and country reports for regional and national S\&T policymaking.

One of the outcomes of RICYT database is its annual publication:

- RICYT (2010). El Estado de la Ciencia - Principales Indicadores de Ciencia y Tecnología - Iberoamericanos/Interamericanos, 2010 [The State of Science: Main Science and Technology Indicators - Ibero-American/Inter-American, 2010]. Buenos Aires, Argentina: Iberoamerican Network of Science and Technology Indicators (RICYT).

\section{[C] Science, Technology and Innovation Indicators in AFRICA}

\section{African Science, Technology E Innovation Indicators Initiative (ASTII) (bttp://wwrw.nepadst. org/astii/index.shtml)}

The African Science Technology and Innovation Indicators (ASTII) Initiative is a programme within the African Science and Technology Consolidated Plan of Action (CPA). The CPA was adopted in 2005 by the African Ministerial Council on Science and Technology $(\mathrm{AMCOST})$ as a framework for STI to respond to the socio-economic challenges facing the continent. The ASTII initiative includes 19 countries: Algeria, Angola, Burkina Faso, Cameroon, Egypt, Ethiopia, Gabon, Ghana, Kenya, Lesotho, Malawi, Mali, Mozambique, Nigeria, Senegal, South Africa, Tanzania, Uganda and Zambia. This activity/programme is supported by the Swedish International Development and Cooperation Agency.

The overall objective of this programme is to build Africa's capacity to develop and use STI indicators. Its specific objectives are to (1) develop and adopt internationally compatible STI indicators (2) build human and institutional capacities for STI indicators and related surveys (3) enable African countries to participate in international programmes for STI indicators; and (4) inform African countries on the state of STI in Africa. It releases reports that cover: Economic and human development challenges for STI; R\&D activities; innovation; Bibliometric analysis of scientific output; and Recommendations to address the challenges identified in it.

Visible outcome of their efforts are reflected in these publications:

- NEPAD (2006) African Science, Technology and Innovation Indicators (ASTII), Towards African Indicator Manuals: A Discussion Document.

- NEPAD (2010) African Innovation Outlook. Achieving this is the challenge. (http://www.nepad.org/humancapitaldevelopment).

The African Innovation Outlook 2010 is published as the first in a series, intended to inform the people of Africa and other interested parties about $S \& T$ indicators activities in African countries.

\section{NATIONAL DATABASES}

\section{[I] NSF-USA Science and Engineering Indicators (http://www.nsf.gov/statistics/seindxx/) ${ }^{1}$}

Science and Engineering Indicators Report is a biennial publication, produced by the National Center for Science and Engineering Statistics (NCSES) of the National Science Foundation, USA. The report provides data and analysis of research trends and performances of $S \& T$ in the United States of America and comparison with other major economies - international S\&T scenario with information on international cooperation and collaborations. It also provides quantitative information on domestic science and engineering enterprises, both public and private domains, as well as science education.

The novelty of this biannual publication is introduction of policy-relevant $S \& T$ indicators that covers different dimensions of the S\&T enterprise and also connects them with socio-economic trends/indications. For example the 2012 report has eight chapters namely: Elementary and secondary mathematics and science education; Higher education in science and engineering; Science and engineering labor force; R\&D: National trends and international comparisons; Academic research and development; Industry, technology, and the global marketplace; Science and technology: Public attitudes and understanding; and State

${ }^{1} x x$ denotes the year to be specified; for example for 2012 report $x x$ is 12, 2010 report $x x$ is 10 and so on. 
indicators. The biennial publications are available online, where reader can browse chapter-wise or download the full report. Some other relevant S\&T statistics, compiled by the NCSES, are available at http://www.nsf.gov/statistics/. The citation and url of the latest report is:

- National Science Board (2012), Science and Engineering Indicators 2012. Washington DC: National Science Foundation. URL: (http://www.nsf.gov/statistics/ seind12/).

It is also available as an Interactive Science and Engineering Indicators 2012 Digest (http://www.nsf.gov/statistics/ digest12/).

\section{(II) Other National S\&T Statistics and STI Indicators}

National STI indicators are also being produced at regular intervals by many other countries. An indicative list of few such publications is given herewith:

- Japanese Science and Technology Indicators. Produced by Research Unit for Science and Technology Analysis and Indicators, National Institute of Science and Technology Policy (NISTEP). URL: http://www.nistep.go.jp/indexe.html

- Malaysian Science and Technology Indicators. Produced by Malaysian Science and Technology Information Centre (MASTIC). URL: www.mastic.gov.my/

- OST Report on Science and Technology Indicators-France. Produced by Observatoire des Sciences et des Techniques (OST), Paris, France. URL: http://www.obs-ost.fr/fr/ le-savoir-faire/etudes-en-ligne/travaux-2010-et-2011/ rapport-biennal-edition-2010.html

- Research and Development Statistics-India. Produced by National Science and Technology Management Information System (NSTMIS), Department of Science and Technology. URL: http://www.nstmis-dst.org/ Publication.htm

- Science and Technology Indicators-Netherlands. Produced by Dutch Observatory of Science and Technology (NOWT). URL: http://nowt.merit.unu.edu/nieuwste_ rapport.php

- Science, Technology \& Innovation Indicators in the State of São Paulo/Brazil. Produced by São Paulo Research Foundation (FAPESP). URL: http://www.fapesp.br/en/ 6541

- South African Science and Technology Indicators. Produced by South Africa Indicators Reference Group, National Advisory Council on Innovation, URL: http://www. innovationeasterncape.co.za/download/sti_2010.pdf

- Science, Technology and Innovation System-Canada. Produced by Science, Technology and Innovation Council, Ottawa, Canada 2011. URL: http://www. stic-csti.ca/eic/site/stic-csti.nsf/eng/h_00006.html

\section{WEB BASED S\&T INDICATORS}

\section{[1] Webometrics Ranking of World Universities (http://www.webometrics.info)}

The Ranking Web of World Universities (or Webometrics Ranking) is an initiative to measure web performance of more than 20,000 higher education institutions across the world. This is a global initiative of Cybermetrics Lab of CSIC, the largest public research body in Spain. The ranking is published twice a year based on data collected during the first weeks of January and July. As its subset, this portal provides web ranking of research centres, business schools, hospitals, and repositories. This portal also provides web ranking of universities in different regions, sub-regions and countries (e.g., Top USA \& Canada; Top Latin America; Top Europe; Top Central \& East Europe; Top Asia; Top South East Asia; Top South Asia; Top Arab World; Top Africa; Top Sub-Saharan Africa; and Country Scoreboard). Based on data available with this portal, several webometric studies were carried out and research results published in international journals, as indicated in its News section.

[2] The WISER Project (Web Indicators for Science, Technology and Innovation Research) (http://www. wiserweb.org and http://www.webindicators.org)

The Web Indicators for Science, Technology and Innovation Research (WISER) is a consortium based project initiated in November 2002 for the European region to develop a new generation of web based S\&T indicators. Proposed indicators are a mix of traditional S\&T indicators, and qualitative measurement of scientific communication and knowledge production. The members of this research consortium are: The Netherlands Institute for Scientific Information Services (NIWI-KNAW), Netherlands; Science Policy Research Unit (SPRU) at the University of Sussex, United Kingdom; Centro de Informacion y Documentation Cientifica (CINDOC), CSIC, Spain; and Statistical Cybermetrics Research Group (SCRG) at the University of Wolverhampton, United Kingdom. WISER Project proposes to contribute a chapter in European S\&T Indicator Reports (ERSTI), on Web Indicators on Science, Technology and Innovation for the Common European Research Area. WISER Project published a technical report:

- Katz, J. Sylvan (2004). Co-Link Web Indicators of the European Research Area. WISER Working Paper \# 2.1. Sussex, United Kingdom: Science Policy Research Unit. URL: http://www.sussex.ac.uk/Users/sylvank/pubs/ Co-Link.pdf 
Toolkits for Measuring Science Technology and Innovation

The section highlights some of the key initiatives undertaken to develop guidelines/manuals for proper collection of STI statistics and construction of indicators.

\section{A. STI Measurement Toolkits Developed by the OECD}

\section{(I) Frascati Manual: Proposed Standard Practice for} Surveys on Research and Experimental Development (wrw.oecd.org/sti/frascatimanual)

OECD published first edition of Frascati Manual in 1966 as "Proposed Standard Practice for Surveys of Research and Development". Sixth edition is its latest edition, published in 2002 as "Frascati Manual: Proposed Standard Practice for Surveys on Research and Experimental Development". It contains guidelines for collecting national data on research and development (R\&D) through nation-wide R\&D surveys. Frascati Manual outlines three forms of research, viz., basic research, applied research and experimental development. Frascati Manual is widely accepted and used by the UNESCO Institute for Statistics and its affiliated national statistical agencies, responsible for collating national data on research and development (R\&D) and S\&T statistics. Recently, Frascati Manual has also introduced methodology for developing countries prepared or evolved in collaboration with UIS, UNESCO. OECD published its regular updates. Latest updates are: (i) Revised Field of Science and Technology (FOS) Classification (2007), and (ii) New Annex on Measuring RéD in Developing Countries (2012). Frascati Manual is freely downloadable from OECD website.

\section{(II) Oslo Manual: Guidelines for Collecting and Interpreting Innovation Data wwrw.oecd.org/sti/ oslomanual}

OECD published first edition of Oslo Manual in 1992 as "The Measurement of Scientific and Technological Activities: Proposed Guidelines for Collecting and Interpreting Technological Innovation Data”. It contains guidelines for collecting and using data on industrial innovation. Its first edition was tested in community innovation surveys across OECD countries. Its latest third edition published in 2005 as "Oslo Manual: Guidelines for Collecting and Interpreting Innovation Data". This edition introduces new indicators on non-technological innovation and innovation linkages.

Oslo Manual is widely accepted by the national and international agencies for the collection and use of data on innovation activities in industry. This publication is freely downloadable from OECD website.

(III) Canberra Manual:Manual on the Measurement of Human Resources Devoted to Science and Technology bttp://wwrw.oecd.org/dataoecd/34/0/2096025.pdf

OECD published Canberra Manual in 1995 to provide guidelines for the measurement of human resources devoted to science and technology (HRST) and the analysis of such data. It was prepared collaboratively by OECD, Eurostat of the European Commission, UNESCO and the International Labour Organization (ILO). It is widely accepted and used by the UNESCO Institute for Statistics and its affiliated national statistical agencies, responsible for collating national data on HRST.

- OECD (1995), Canberra Manual: Manual on the Measurement of Human Resources Devoted to Science and Technology. Paris: OECD Publishing.

\section{(IV) OECD Patent Statistics Manual (2009) (bttp://wrwr.oecd.org/document/29/0,3746, en_2649_34269_42168029_1_1_1_1,00.html)}

This manual provides guiding principles for the use of patent data in S\&T measurement, and recommendations for the compilation and interpretation of patent indicators in this context. It aims to show what patent statistics can be used for, what they cannot be used for, and how to count patents in order to maximise information on S\&T activities while minimising statistical noise and biases. Finally, it describes how patent data can be used in the analysis of a wide array of topics related to technical change and patenting activity including industry-science linkages, patenting strategies by companies, internationalisation of research, and indicators on the value of patents.

\section{Forerunner of this manual:}

- OECD manual on patents in 1994 ("The Measurement of Scientific and Technological Activities: Using Patent Data as Science and Technology Indicators")

http://www.oecd.org/LongAbstract/0,3425, en_2649_3 4269_2095925_1_1_1_1,00.html

(V) Measuring Innovation: A New Perspective (2010) (wrw.oecd.org/innovation/strategy/measuring)

This document builds on the OECD's half-century experience of indicator development and the challenge presented by the broad horizontal focus of the OECD Innovation Strategy. It identifies five broad areas in which 
international action is needed: develop innovation metrics that can be linked to aggregate measures of economic performance; invest in a high quality and comprehensive statistical infrastructure to analyse innovation at the firmlevel; promote metrics of innovation in the public sector and for public policy evaluation; find new and interdisciplinary approaches to capture knowledge creation and flows; promote the measurement of innovation for social goals and of social impacts of innovation.

\section{B. STI Measurement Toolkit Developed by the UNESCO}

UNESCO is playing a key role in coordinating with national S\&T agencies around the world to create comparable S\&T statistics of different countries; It has also been involved in creating guidelines for proper measurement of STI. Major focus now has been to produce a set of guidelines on how to implement innovation surveys in developing countries. This would complement the Oslo manual which is primarily based on the experiences of the world's most industrialized countries. Guidelines developed by the UNESCO have been published as an annex in the third and most recent edition of the Oslo Manual (2005). They are primarily based on the experiences of countries that have already conducted innovation surveys, most of which are among the higher and medium income countries of the developing world.

\section{STI Measurement Toolkit Developed by RCYIT}

\section{Bogota Manual: Standardisation of Indicators of Technological Innovation in Latin American and Caribbean Countries}

This manual, based on Oslo Frascati and Canberra Manuals and other guidelines, is used to measure science, technology and innovation across Latin America and the Caribbean.

- RICYT(2001). Bogota Manual: Standardisation of Indicators of Technological Innovation in Latin American and Caribbean Countries. Buenos Aires, Argentina: Iberoamerican Network of Science and Technology Indicators (RICYT). URL: http://www.uis.unesco.org/Library/Documents/ Bogota $\% 20$ Manual_eng.pdf

D. STI Measurement Toolkit Developed by the European Commission

\section{Handbook on Constructing Composite Indicators: Methodology and User Guide}

This handbook aims to provide a guide to the construction and use of composite indicators, for policy-makers, academics, the media and other interested parties. While there are several types of composite indicators, this handbook is concerned with those which compare and rank country performance in areas such as industrial competitiveness, sustainable development, globalization and innovation. The handbook aims to contribute to a better understanding of the complexity of composite indicators and to an improvement in the techniques currently used to build them. In particular, it contains a set of technical guidelines that can help constructors of composite indicators to improve the quality of their outputs.

http://composite-indicators.jrc.ec.europa.eu/Handbook.htm

\section{Forerunners of this work are:}

- Tools for Composite Indicators Building. Nardo M., Saisana M., Saltelli A. and Tarantola S., 2005, European Commission, EUR 21682 EN, Institute for the Protection and Security of the Citizen, JRC Ispra, Italy.

- State-of-the-art Report on Current Methodologies and Practices for Composite Indicator Development, 2002, M. Saisana, S. Tarantola, EUR 20408 EN, European Commission-JRC, Italy.

- OECD Statistics Working Paper-Handbook On Constructing Composite Indicators: Methodology and User Guide, 2005, Nardo, M., M. Saisana, A. Saltelli and S. Tarantola (EC/JRC), A. Hoffman and E. Giovannini (OECD), JT00188147, STD/DOC (2005) 3.

[E] National Initiatives in the Development of STI Measurement Toolkit

Along with regional efforts, different countries have been involved in developing novel indicators, providing clarity in data collection and in creating data sets for long trend analysis, etc. The influential role played by the USA and Japan through their two federal agencies namely NSF: National Science Foundation and NISTEP: National Institute of Science and Technology Policy requires special mention. Each of the Science and Engineering Indicators report of the NSF (a biannual report) is a testimony of this effort. NISTEP has been actively involved with OECD in their indicator development efforts. The NISTEP especially played a major role in the development of composite S\&T indicator and their construction. See for example NISTEP: Report No. 37. Science and Technology Indicators: 1994.

http://www.nistep.go.jp/achiev/ftx/eng/rep037e/pdf/ rep037e.pdf 


\section{ACKNOWLEDGEMENTS}

We thank Dr Divya Srivastava, Scientist, ICMR for her insightful comments and inputs. We thank Ms A.P. Jayanthi for her help in identifying useful links. Thank Dr B.M. Gupta and Dr K.C. Garg for their encouragement in developing this webliography section.

Authors Note: All efforts have been taken to check the authenticity and correctness of the information provided in this webliography. However, the authors take responsibility for any mistakes. This webliography highlights some of the active entities involved in STI indicator development. The present webliography has not covered research groups that are playing a key role in indicator development. It has also not covered the specialised conferences and journals that have played a major role in the development of the scientific community in this domain. This webliography series will examine them in future contributions. This series will highlight work of other international and national entities whose work is playing an influential role in this area. 